\title{
PENGARUH PEMBERIAN TERAPI TOKEN EKONOMI TERHADAP PENINGKATAN PERSONAL HYGIENE PADA PASIEN DENGAN DEFISIT PERAWATAN DIRI DI RUMAH SAKIT JIWA PROVINSI BALI
}

\section{(The Influence of Economic Token Therapy On The Improvement Of Personal Hygiene In Patients With Self-Deficit in Mental Hospital of Bali Province)}

\author{
Made Martini $^{1}$, Ari Pertama Watiningsih ${ }^{2}$ \\ Program Studi S1 Keperawatan, Sekolah Tinggi Ilmu Kesehatan Buleleng \\ e-mail: mademartini20@gmail.com
}

\begin{abstract}
ABSTRAK
Pendahuluan: Defisit perawatan diri merupakan suatu keadaan seseorang yang mengalami kelainan dalam kemampuan untuk dapat melakukan atau menyelesaikan aktivitas kehidupan sehari-hari secara mandiri. Kurangnya perawatan diri terjadi akibat adanya perubahan proses pikir sehingga kemampuan untuk melakukan aktifitas perawatan diri menurun. Metode token ekonomi merupakan sebuah system reinforcement untuk perilaku yang dikelola dan diubah, seseorang mesti dihadiahi/diberikan penguatan untuk meningkatkan atau mengurangi perilaku yang diinginkan. Tujuan penelitian ini untuk mengetahui ada pengaruh terapi token ekonomi terhadap peningkatan personal hygiene pada pasien dengan defisit perawatan diri di rumah sakit jiwa provinsi bali . Metode : Desain penelitian adalah pra eksperimental dengan rancangan one group pre-post test design dengan sampel 33 responden yang dipilih menggunakan teknik nonprobability sampling dengan kriteria sampel. Pengukuran tingkat personal hygiene dilakukan dengan lembar observasi skala likert.. Penelitian ini menggunakan uji Paired $t$-test dengan tarah signifikan $\alpha=0,05$. Hasil : Didapatkan hasil data nilai rata - rata pre 10,58 dan nilai rata-rata post 13,79 . Hasil uji menggunakan uji Paired t-test didapatkan nilai p pre dan post $(0,001)<\alpha(0,05)$, artinya $\mathrm{H}_{0}$ ditolak dan $\mathrm{H}_{\mathrm{a}}$ diterima. Sehingga disimpulkan ada pengaruh pemberian terapi token ekonomi terhadap peningkatan personal hygiene pada pasien dengan defisit perawatan diri di rumah sakit jiwa provinsi bali.
\end{abstract}

Kata kunci: Terapi Token Ekonomi, Personal Hygiene

\begin{abstract}
The deficit of self-care is a state of a person who is experiencing abnormalities in the ability to be able to perform or complete daily activities of life independently. Lack of self-care occurs due to a change of thought process so that the ability to perform self-care activities decreased. The economic token method is a system of reinforcement for behaviors that are managed and changed, one must be rewarded / given reinforcement to increase or decrease the desired behavior. the purpose of this study was to determine the effect of economic token therapy on improving personal hygiene in patients with self care deficits in provincial mental hospital. Methods: The research design was pre-experimental with one group pre-post test design with 33 respondents which was chosen through non-probability sampling technique with sample criteria. Measuring the level of personal hygiene is done with a likert scale. This study uses a paired t-test with significant $\alpha=0,05$. Result: obtained the result of the average pre test 10,58 and post test 13,79 . Test result using paired t test pre and post test $(0,001)<\alpha$ $(0,05)$, this means than $\mathrm{H}_{0}$ is rejected and $\mathrm{H}_{\mathrm{a}}$ accepted. So it can be concluded that there is an effect of economic token therapy on increasing personal hygiene in patients with self-care deficits in bali provincial mental hospital.
\end{abstract}

Keywords : Economy Token, Personal Hygiene

Kesehatan jiwa merupakan suatu kondisi dimana seseorang mampu berkembang http://ejournal.stikesbuleleng.ac.id/index.php/Midwinerslion | 58 
baik secara fisik, mental, sosial dan spiritual sehingga individu mampu menyadari kemampuannya sendiri, serta mampu mengatasi tekanan, mampu bekerja produktif, dan dapat memberikan kontribusi bagi komunitasnya (Undang-undang kesehatan jiwa, 2014)

Gangguan jiwa merupakan sindrom perilaku atau psikologis yang bermakna secara klinis ditandai dengan pasien mengalami distress, kecacatan atau berisiko menderita cacat atau hilangnya kebebasan, gangguan jiwa mengacu kepada semua kelainan mental seperti gangguan berpikir pada penyakit alzeimer, gangguan mood pada orang yang mengalami depresi dan perubahan perilaku yang mungkin muncul pada orang dengan skizofrenia atau pasien mungkin akan menunjukkan gejala gabungan. (Varcarolis \& Halter, 2010).

Tanda dan gejala pada gangguan jiwa berbeda-beda untuk setiap diagnosa menurut Diagnostic and Statistical Manual of Mental Disorder, Fifth Edition (DSM-V, 2013) Pada gangguan mood pasien dapat mengalami depresi, manik, hipomanik dan bipolar. Pada pasien yang mengalami kecemasan dapat menampilkan gejala kepanikan, phobia, dan stress posttraumatik. Pada gangguan jiwa berat gejala yang dapat muncul antara lain berupa halusinasi, ilusi, waham, gangguan proses pikir dan kemampuan berpikir, serta tingkah laku aneh, misalnya agresifitas atau katatonik. Gejala-gejala diatas dapat mempengaruhi pasien dalam melakukan kegiatan sehariharinya, seperti terganggunya kegiatan perawatan diri. Keterbatasan pada pasien defisit perawatan diri biasanya dapat diakibatkan karena stressor yang berat serta sulit dihadapi oleh klien, sehingga dirinya sulit atau tidak mau untuk mengurus atau merawat dirinya sendiri baik untuk mandi, berpakaian, berhias, makan, serta BAB dan BAK. apabila tidak dilakukan perawatan atau intervensi oleh perawat maka kemungkinan besar klien akan mengalami masalah resiko tinggi isolasi sosial (Nasution,2013).

Menurut Riskesdas (2016) terdapat sekitar 35 juta orang terkena depresi, 60 juta orang terkena bipolar, 21 juta orang terkena skizofrenia, serta 47,5 juta terkena dimensia. Jumlah penderita gangguan jiwa di indonesia saat ini adalah 236 juta orang, dengan kategori gangguan jiwa ringan $6 \%$, gangguan jiwa berat $0,17 \%$, mengalami pasung $14,3 \%$. Gangguan jiwa berat terbanyak di Yogyakarta, Aceh, Sulawesi Selatan, Bali, dan Jawa Tengah. Sedangkan pada Provinsi Bali, prevalensi gangguan jiwa berat sebesar 2,3\%. Prevalensi gangguan jiwa emosional pada penduduk yang berumur $\geq 15$ tahun di Indonesia sebesar 4,0 \% dengan prevalensi gangguan jiwa emosional yang tertinggi adalah Provinsi Sulawesi Tengah, diikuti oleh Provinsi Sulawesi Selatan, Jawa Barat dan DI Yogyakarta, sedangkan pada Provinsi Bali, prevalensi penduduknya mengalami gangguan jiwa emosional sebesar $4,4 \%$.

Bali memiliki jumlah penduduk sebesar 3.890.757 jiwa (BPS, 2010). Ini berarti, penduduk di Bali yang mungkin mengalami gangguan jiwa sebesar 8.948 jiwa dan yang mungkin mengalami gangguan mental emosional sebesar 15.563 jiwa.

Defisit perawatan diri merupakan suatu keadaan dimana seseorang mengalami kelainan atau tidak mampu menyelesaikan aktivitas secara mandiri dan tidak ada keinginan untuk mandi secara teratur, tidak menyisir rambut, pakaian kotor, bau badan, bau nafas, dan penampilan tidak rapi ( Ah yusuf dkk, 2014).

Ada beberapa terapi yang dapat dilakukan untuk merubah gangguan perilaku klien defisit perawatan diri diantaranya adalah terapi kognitif, terapi lingkungan, terapi keluarga, terapi kelompok, terapi psikoreligius, terapi individu dan terapi perilaku. Salah satu jenis terapi perilaku yang bisa digunakan disini adalah dengan terapi token ekonomi yang merupakan sebuah prosedur modifikasi perilaku yang menggunakan reinforcement positif yang sering digunakan untuk mengubah atau menghindari perilaku yang buruk pada klien (Yosep\&Titin, 2014).

Token ekonomi merupakan sebuah prosedur modifikasi perilaku dengan menggunakan reinforcement positif yaitu pemberian suatu kepingan atau tanda sesegera mungkin setiap kali setelah perilaku sasaran muncul. Token ekonomi merupakan sebuah sistem reinforcement, untuk perilaku yang dikelola dan diubah seseorang mesti dihadiahi atau diberikan penguatan untuk meningkatkan http://ejournal.stikesbuleleng.ac.id/index.php/Midwinerslion | 59 
atau mengurangi perilaku yang diinginkan (Garry\&Joseph, 2015).

Dalam penelitian Nike Azlina, dkk (2017) tentang "Pengaruh Penerapan Teknik Token Economy Terhadap Toilet Training Pada Anak Usia 2-3 Tahun Di TPA IT Future Islamic School Kecamatan Payung Sekaki Kota Pekanbaru" dengan hasil yang diperoleh $Z_{\text {hitung }}=2,032$ dan sig. (2-tailed) $=0,042$. Karena Sig. (2-tailed) $=0,04<0,05$ maka dapat disimpulkan bahwa ada perbedaan kemampuan toilet training anak yang signifikan sesudah penerapan teknik token economy dalam pembelajaran.

Sejalan dengan penelitian khuzaimah (2017) "Efektivitas Penggunaan Teknik Token Ekonomi Terhadap Perilaku Prokartinasi Akademik Mahasiswa Program Studi Psikologi FKIK Universitas Jambi" dengan hasil uji statistik menggunakan teknik Paired data $t$-test menunjukkan bahwa terdapat perbedaan perilaku prokrastinasi akademik mahasiswa sebelum dan sesudah diberikan token ekonomi dengan nilai signifikan 0,047 . Perbedaan signifikan 0,07 dan terdapat pengurangan mean sebesar 2,58. Perbedaan perilaku ditunjukkan lebih signifikan pada prokrastinasi maladaftif dengan signifikan 5\% $p=0,007(\mathrm{p}<0,05)$ yang berarti $\mathrm{H}_{0}$ ditolak dan terdapat pengaruh token ekonomi terhadap perilaku Prokartinasi Akademik Mahasiswa Program Studi Psikologi FKIK Universitas Jambi.

Berdasarkan studi pendahuluan yang dilakukan oleh peneliti di Rumah Sakit Jiwa Bangli pada tanggal 13 Oktober 2018, berdasarkan rekam medik pada tahun 2017 terdapat 5.302 pasien rawat inap dan sebanyak 97\% (5.169) dari 5.302 pasien dengan skizofrenia. Selain itu Berdasarkan informasi dari beberapa ruangan di Rumah Sakit Jiwa Provinsi Bali terdapat 46 pasien. Setelah dilakukan observasi terhadap 10 pasien dengan defisit perawatan diri, terdapat 3 pasien tidak melakukan perawatan diri dengan berhias seperti menyisir rambut, 4 pasien malas untuk melakukan aktifitas kebersihan diri seperti menggosok gigi setelah makan, dan 3 pasien malas untuk mandi. Dari data diatas dan berdasarkan informasi dari ketujuh kepala ruangan mengatakan bahwa pasien dengan Defisit Perawatan Diri cenderung untuk tidak mau menggosok gigi, mandi dan menyisir rambut dan dari hasil wawancara dari beberapa perawat di ruangan yang biasa dilakukan perawat pada saat pasien tidak mau melakukan perawatan diri hanya ditegur. dan di Rumah Sakit Jiwa Bangli belum pernah menerapkan terapi keperawatan lain termasuk token ekonomi bagi klien dengan defisit perawatan diri.

Dari uraian diatas maka peneliti tertarik untuk mengangkat judul penelitian "Pengaruh Pemberian Terapi Token Ekonomi Terhadap Peningkatan Personal Hygiene Pada Pasien Defisit Perawatan Diri Di Rumah Sakit Jiwa Provinsi Bali”.

\section{METODE PENELITIAN}

Desain Penelitian ini menggunakan Pre Experimental dengan rancangan desain One Group Pretest Posttest dimana rancanga ini tidak ada kelompok pembanding (control), tetapi disini telah melakukan observasi pertama (pretest) yang akan memungkinkan menguji adanya perubahan - perubahan yang ada setelah dilakukannya eksperimen (program) (Notoatmodjo, 2012). Penelitian ini dilakukan di Rumah Sakit Jiwa Provinsi Bali.

Alat yang digunakan untuk mengumpulkan data pada penelitian ini berupa lembar observasi personal hygiene skala likert. Lembar observasi tersebut berisi data demografi responden terdiri dari nama, usia, jenis kelamin dan pendidikan.

\section{HASIL PENELITIAN DAN PEMBAHASAN}

Sampel penelitian ini adalah pasien gangguan jiwa dengan defisit perawatan diri. Adapun karakteristik sampel penelitian ini adalah sebagai berikut:

Tabel 4.1 Gambaran Karakteristik Responden Berdasarkan umur

\begin{tabular}{lllllll}
\hline & N & Mean & Min & Max & SD & 95\% CI \\
\hline Umur & 33 & 39,76 & 23 & 55 & 8,9 & $-3,564$ \\
& & & & & & $-2,860$ \\
\hline
\end{tabular}

Berdasarkan tabel 4.1 dapat disimpulkan bahwa umur termuda responden http://ejournal.stikesbuleleng.ac.id/index.php/Midwinerslion | 60 
adalah 23 tahun dan umur tertua adalah 55 tahun. Dari 33 orang responden rata-rata (mean) umur responden adalah 39,76.

Tabel 4.2 Gambaran Karakteristik Responden Berdasarkan pendidikan

\begin{tabular}{ccc}
\hline Pendidikan & Frekuensi & $\begin{array}{c}\text { Persentase } \\
(\boldsymbol{\%})\end{array}$ \\
\hline $\begin{array}{c}\text { Tidak } \\
\text { Sekolah }\end{array}$ & 12 & 36,4 \\
\hline SD & 10 & 30,3 \\
\hline SMP & 8 & 24,2 \\
\hline SMA & 3 & 9,1 \\
\hline
\end{tabular}

Berdasarkan tabel 4.2 dapat disimpulkan bahwa pasien yang tidak sekolah paling banyak sebanyak 12 orang $(36,4 \%)$, dan paling sedikit berpendidikan SMA sebanyak 3 orang $(9,1 \%)$ dari 33 orang dari penelitian ini.

Tabel 4.3 Skor Tingkat Personal Hygiene Sebelum Terapi Token Ekonomi

\begin{tabular}{lllllll}
\hline & N & Mean & Min & Max & SD & $\begin{array}{l}\text { 95\% } \\
\text { CI }\end{array}$ \\
\hline $\begin{array}{l}\text { Pre } \\
\text { test }\end{array}$ & 33 & 10,58 & 8 & 14 & 1,37 & $10,09-$ \\
& & & & 0 & 11,06 \\
\hline
\end{tabular}

Berdasarkan tabel 4.3 menunjukan bahwa rata-rata skor tingkat personal hygiene sebelum diberikan terapi token ekonomi dari 33 responden 10,58 (95\% CI

10,09-11,06), dengan standar deviation 1,370 skor tingkat personal hygiene terendah 8 dan tertinggi 14. Dari estimasi interval disimpulkan bahwa 95\% diyakini bahwa rata-rata tingkat personal hygiene yaitu 10,09 sampai dengan 11,06 .

Tabel 4.4 Skor Tingkat Personal Hygiene Setelah Diberikan Terapi Token Ekonomi

\begin{tabular}{|l|l|l|l|l|l|l|}
\hline & N & Mean & Min & Max & SD & $\begin{array}{l}\text { 95\% C } \\
\text { I }\end{array}$ \\
\hline $\begin{array}{l}\text { Post } \\
\text { test }\end{array}$ & 33 & 13,79 & 11 & 16 & 1,219 & $\begin{array}{l}13,36- \\
14,22\end{array}$ \\
\hline
\end{tabular}

Berdasarkan tabel 4.4 menunjukan bahwa rata-rata skor tingkat personal hygiene setelah diberikan terapi token ekonomi dengan 33 responden 13,79 (95\% CI 13,36-14,22), dengan standar deviation 1,219 skor tingkat personal hygiene terendah 11 dan tertinggi 16. Dari estimasi interval disimpulkan bahwa $95 \%$ diyakini bahwa rata-rata tingkat personal hygiene pada pasien dengan defisit perawatan diri yaitu 13,36 sampai dengan 14,22.

Tabel 4.5 Uji Normalitas

\begin{tabular}{|c|c|c|c|}
\hline & Satistic & $d f$ & $\begin{array}{l}\text { Hasil } \\
\text { Bagi }\end{array}$ \\
\hline $\begin{array}{l}\text { Sebelum } \\
\text { Intervensi }\end{array}$ & 0,944 & 33 & 0,087 \\
\hline $\begin{array}{l}\text { Sesudah } \\
\text { Intervensi }\end{array}$ & 0,938 & 33 & 0,059 \\
\hline
\end{tabular}

Dari tabel 4.5 dapat dilihat bahwa dari uji normalitas dengan menggunakan shapiro wilk hasil bagi sebelum dan setelah intervensi $(>0,005)$ yaitu sebelum intervensi 0,087 dan setelah intervensi 0,059 maka dapat disimpulkan bahwa data berdistribusi normal. Karena data berdistribusi normal maka uji statistik yang tepat adalah uji beda parametrik yaitu uji Paired t-test.

Tabel 4.6 Hasil Uji Pre dan Post Test Dengan Menggunakan Uji Paired t- Test

\begin{tabular}{|c|c|c|c|c|c|}
\hline \multirow{2}{*}{$\begin{array}{l}\text { Terapi } \\
\text { token } \\
\text { ekonom } \\
\mathrm{i}\end{array}$} & \multirow{2}{*}{$\begin{array}{l}\text { Mea } \\
\text { n } \pm \\
\text { SD }\end{array}$} & \multirow{2}{*}{$\begin{array}{l}\text { Beda } \\
\text { Rerat } \\
\text { a }\end{array}$} & \multirow{2}{*}{$\begin{array}{l}\text { Nilai } \\
\text { p }\end{array}$} & \multicolumn{2}{|c|}{$95 \% \mathrm{CI}$} \\
\hline & & & & $\begin{array}{l}\text { Low } \\
\text { er }\end{array}$ & Upper \\
\hline Pre test & $\begin{array}{l}10,58 \\
\pm 1,4\end{array}$ & $-3,21$ & $\begin{array}{l}<0,0 \\
01\end{array}$ & $-3,56$ & $-2,86$ \\
\hline Post test & $\begin{array}{l}13,79 \\
\pm 1,2\end{array}$ & & & & \\
\hline
\end{tabular}

Tabel 4.6 diatas menunjukkan bahwa rata-rata tingkat personal hygiene sebelum diberikan terapi dengan sesudah diberikan terapi terdapat perbedaan dengan beda rerata sebelum dan sesudah diberikan terapi yaitu 3,21. Hasil uji yang dilakukan dengan menggunakan uji paired $t$-test menunjukan bahwa sig. (2-tailed) atau nilai $p$ value $=0,001$ 
dan nilai 95\%CI $(-3,56-(-2,86))$. Karena nilai $\mathrm{p}$ lebih kecil dari $0,05(\mathrm{p}>\alpha)$ maka hipotesis nol $\left(\mathrm{H}_{0}\right)$ ditolak dan hipotesis alternative $\left(\mathrm{H}_{\mathrm{a}}\right)$ diterima. Sehingga dapat disimpulkan ada pengaruh pemberian terapi token ekonomi terhadap peningkatan personal hygiene pada pasien dengan defisit perawatan diri di rumah sakit jiwa provinsi bali.

Karakteristik responden berdasarkan umur menunjukkan bahwa dari 33 berdasarkan karakteristik umur didapatkan rata rata responden 39,76 tahun. Umur yang paling tua 55 tahun dan yang paling muda 23 tahun, dan berdasarkan karakteristik pendidikan didapatkan Sebagian besar responden berpendidikan terakhir tidak sekolah yaitu sebanyak $36,4 \%$.

Berdasarkan umur berkaitan erat dengan tingkat kedewasaan atau maturitas, yang berarti bahwa semakin meningkat usia seseorang akan semakin meningkat pula kedewasaannya atau kematangannya baik secara teknis, maupun psikologis, serta semakin mampu melaksanakan tugasnya. Usia merupakan salah satu faktor yang dapat mempengaruhi tingkat perilaku seseorang (Abdul, 2015).

Karakteristik responden berdasarkan pendidikan menunjukkan bahwa dari 33 responden yang menjadi karakteristik dari subjek penelitian berdasarkan karakteristik pendidikan didapatkan hasil bahwa pasien yang tidak sekolah paling banyak sebanyak 12 orang $(36,4 \%)$, dan paling sedikit berpendidikan SMA sebanyak 3 orang $(9,1 \%)$.

Pengetahuan tentang pentingnya personal hygiene dan implikasinya bagi kesehatan mempengaruhi praktik hygiene. Dari hal itu sendiri pengetahuan tidaklah cukup. Pasien juga harus termotivasi untuk memelihara perawatan diri (Potter dan Perry, 2012).

Hasil uji analisa data dengan menggunakan uji paired $t$-test menunjukkan bahwa nilai $\mathrm{p}<\alpha \quad(0,001<0,005) \quad$ dengan demikian hipotesis nol $\left(\mathrm{H}_{0)}\right.$ ditolak. Penelitian ini membuktikan adanya pengaruh terapi token ekonomi terhadap peningkatan personal hygiene pada pasien defisit perawatan diri di rumah sakit iwa provinsi bali.
Token ekonomi memang bukan terapi khusus yang digunakan untuk mengatasi defisit perawatn diri, tetapi dengan adanya pemberian reward mampu membuat perasaan senang terhadap klien. Dari adanya pujian dan pemberian reward dapat meningkatkan aktifitas kebersihan diri pada pasien (Purwanta, 2015).

Hasil penelitian tersebut sejalan Heppi Sasmita dkk, 2012) "Pengaruh Metode Token Economy Terhadap Aktifitas Perawatan Diri Pada Pasien Defisit Perawatan Diri" didapatkan hasil bahwa ada pengaruh metode token ekonomi terhadap peningkatan aktifitas perawatan diri dengan hasil uji statistik $\mathrm{p}<$ 0,05 .

\section{KESIMPULAN DAN SARAN Kesimpulan}

Karakteristik responden berdasarkan umur termuda adalah 23 tahun dan umur tertua adalah 55 tahun dengan rata-rata 39,76 tahun. Karakteristik responden berdasarkan pendidikan dapat disimpulkan sebagian besar responden berpendidikan terakhir tidak sekolah yaitu sebanyak $36,4 \%$. Tidak sekolah 12 orang $(36,4 \%)$, SD 10 orang $(30,3 \%)$, SMP 8 orang $(24,2 \%)$, SMA 3 orang $(9,1 \%)$.

Karakteristik responden berdasarkan pendidikan menunjukkan bahwa dari 33 responden yang menjadi karakteristik dari subjek penelitian berdasarkan karakteristik pendidikan didapatkan hasil bahwa pasien yang tidak sekolah paling banyak sebanyak 12 orang $(36,4 \%)$, dan paling sedikit berpendidikan SMA sebanyak 3 orang $(9,1 \%)$.

Berdasarkan hasil pengukuran tingkat personal hygiene sebelum melakukan terapi token ekonomi dapat disimpulkan bahwa didapatkan nilai rata-rata 10,58 dengan nilai terendah 8 dan nilai tertinggi 14 .

Berdasarkan hasil pengukuran tingkat personal hygiene setelah diberikan intervensi dapat disimpulkan bahwa didapatkan nilai ratarata 13,79 dengan nilai terendah 11 dan nilai tertinggi 16, standar deviation 1,2.

Hasil uji analisa data dengan menggunakan uji paired t-test menunjukkan bahwa nilai $\mathrm{p}<\alpha \quad(0,001<0,005) \quad$ dengan demikian hipotesis nol $\left(\mathrm{H}_{0)}\right.$ ditolak. Penelitian ini membuktikan adanya pengaruh terapi token http://ejournal.stikesbuleleng.ac.id/index.php/Midwinerslion | 62 
ekonomi terhadap peningkatan personal hygiene pada pasien defisit perawatan diri di rumah sakit iwa provinsi bali.

\section{SARAN}

Berdasarkan kesimpulan di atas, maka dapat dikemukakan beberapa saran yaitu bagi RSJ Provinsi Bali diharapkan dapat memberikan terapi token ekonomi sebagai salah satu terapi nonfarmakologi untuk meningkatkan personal hygiene pasien.

\section{REFERENSI}

Ah Yusuf. Rizky \& Hanik. (2015). Buku Ajar Keperawatan Kesehatan Jiwa. Jakarta: Salemba Medika

Garry, M \& Joseph (2015). Modifikasi Perilaku:Makna dan Penerapannya edisi10. Yogyakarta: Pustaka Pelajar.

Khuzaimah. (2017). Efektivitas Penggunaan Teknik Token Ekonomi Terhadap Perilaku Prokartinasi Akademik Mahasiswa Program Studi Psikologi FKIK Universitas Jambi. Psycho Idea

Nasution. (2013). Asuhan Keperawatan pada Pasien Dengan Penerapan Personal Hygiene.

Dalam http://www.nersgun.multiply.multiply content.com diakses tanggal 24 Mei 2018

Nike Azlina, dkk. (2017). Pengaruh Penerapan Teknik Token Economy
Terhadap Toilet Training Pada Anak Usia 2-3 Tahun Di TPA IT Future Islamic School Kecamatan Payung Sekaki Kota Pekanbaru

Notoatmodjo, Soekidjo.(2012).Metodelogi Penelitian Kesehatan.Jakarta: PT Rineka Cipta.

Riskesdas. (2016). Riset Kesehatan Dasar direkomendasikan oleh Kementrian Kesehatan Indonesia 2016 tersedia http://www.depkes.go.id/article/print/1 6100700005/peran-keluargadukungan-kesehatan-jiwamasyarakat.html diakses tanggal 20 Mei 2018

Sasmita Heppi, dkk. (2012). Pengaruh Metode Token Economy Terhadap Aktifitas Perawatan Diri pada Pasien Defisit Perawatan Diri. Ners Jurnal Keperawatan, 4 (2). 23-30

\section{UNDANG-UNDANG REPUBLIK} INDONESIA NOMOR

18TAHUN , 2014 TENTANG KESEHATAN JIWA oleh, Presiden Republik Indonesia2014 tersedia file://C:Users/GANESACARE/ Downloads/UU\%20182014\%20Kesehatan \%20Jiwa.pdf Diakses 28 April 2018 